\title{
Microvertebrates preserved in mammal burrows from the Holocene of the Argentine Pampas: a taphonomic and paleoecological approach
}

\author{
Rodrigo Leandro Tomassinia , Claudia Inés Montalvo ${ }^{b}$, Elisa Beilinsonc, Cecilia María Deschamps ${ }^{d}$ \\ Mariana Carolina Garrone ${ }^{\mathrm{e}}$, German Mariano Gasparinif, Marcelo Arístides Zárateg, Jorge Rabassah ${ }^{\text {, }}$ Agustín Ruella ${ }^{\mathrm{i}}$ \\ and Eduardo Pedro Tonni
}

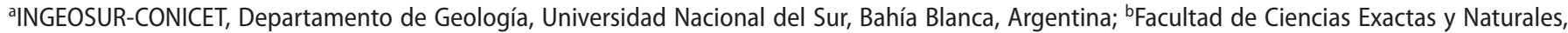
Universidad Nacional de La Pampa, Santa Rosa, Argentina; 'CIG-CONICET, Universidad Nacional de La Plata, La Plata, Argentina; ${ }^{d}$ CIC, División Paleontología Vertebrados, Museo de La Plata, Universidad Nacional de La Plata, La Plata, Argentina; 'Departamento de Geología, Universidad Nacional del Sur, Bahía Blanca, Argentina; ${ }^{\mathrm{f} C O N I C E T}$, División Paleontología Vertebrados, Anexo Museo de La Plata, Universidad Nacional de La Plata,

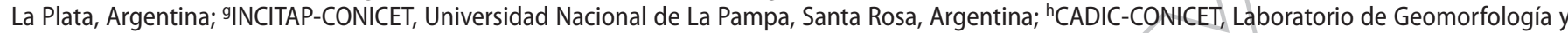
Cuaternario, Universidad Nacional de Tierra del Fuego, Ushuaia, Argentina; 'Facultad de Ciencias Naturales y Museo, Universidad Nacional de La Plata,

\begin{abstract}
Microvertebrates are a major component of many assemblages recovered from the Quaternary of the Argentine Pampas. The main goal of this paper is to analyse the taphonomic history of a Holocene microfossil bonebed, recovered from the infilling of a burrow. Evidences suggest the plains vizcacha Lagostomus maximus as the putative producer of the burrow. The assemblage includes individuals belonging to different taxa of mammals (marsupials and rodents) and reptiles (snakes). Taphonomic features suggest that the accumulation inside the burrow was related to flooding processes in the plain. The burrow was a natural trap that favoured the accumulation and preservation of remains corresponding to individuals from different sources. According to the taphonomic evidence, some individuals (Lagostomus maximus, Lestodelphys halli and Serpentes indet.) died inside the burrow, whereas others (Microcavia australis, Reithrodon auritus and Ctenomys sp.) died outside the burrow, and after a time of being exposed on the surface their remains were transported by surface run-offs into the burrow. The record of Lestodelphys halli and Serpentes indet. in the burrow produced by Lagostomus maximus could be related to a circumstantial use. Mammal burrows are a significant taphonomic mode for the late Cenozoic of the Argentine Pampas.
\end{abstract}

\section{ARTICLE HISTORY}

Received 30 October 2015

Accepted 23 November 2015

\section{KEYWORDS}

Taphonomy; microvertebrates; mammal burrows; natural traps; Argentine Pampas

\section{Introduction}

Micromammal remains are common in numerous Cenozoic continental deposits (e.g. Badgley 1986; Behrensmeyer and Hook 1992). Considering their usefulness for biochronologic, biostratigraphic, paleoenvironmental, paleoclimatic and paleoecologic studies, it is essential to know the processes that took part in the formation of the assemblages (Andrews 1990; Fernández-Jalvo et al. 2014). In this sense, burrows have been proposed as favourable contexts for the preservation of skeletal elements Behrensmeyer and Hook (1992; and references therein).

The vertebrate fauna from the late Cenozoic of the Pampean Region, central Argentina, is one of the richest and most diverse of South America (Cione and Tonni 2005; Cione et al. 2015). Particularly, microvertebrates are a major component of many assemblages. The presence of remains inside burrows has been highlighted by numerous authors for the late Miocenelate Holocene of the Argentine Pampas (e.g. Genise 1989;
Scognamillo 1993; Peña 1997; Elissamburu et al. 2011; Beilinson and Taglioretti 2013; Tomassini and Montalvo 2013; Cenizo et al. 2015). However, the origin of small vertebrates assemblages is barely studied taphonomically (e.g. Pardiñas 2001, 2004; Cenizo and De los Reyes 2008; Montalvo et al. 2012, 2015; Cenizo et al. 2015).

This paper is focused on the taphonomic features of a microvertebrate assemblage found in the fossiliferous locality Puente Vanoli, middle reach of the Quequén Salado River (Buenos Aires Province, southern of the Pampean Region). The assemblage is Holocene in age and was recovered from the infilling of a small cavity developed in floodplain deposits, interpreted as a burrow probably produced by the chinchillid rodent Lagostomus maximus. Given that the burrows are very abundant in the fossil record and offer a context for the accumulation and preservation of small vertebrates, their importance as a taphonomic mode (sensu Behrensmeyer and Hook 1992) in the Argentine Pampas for the late Cenozoic is also evaluated. 


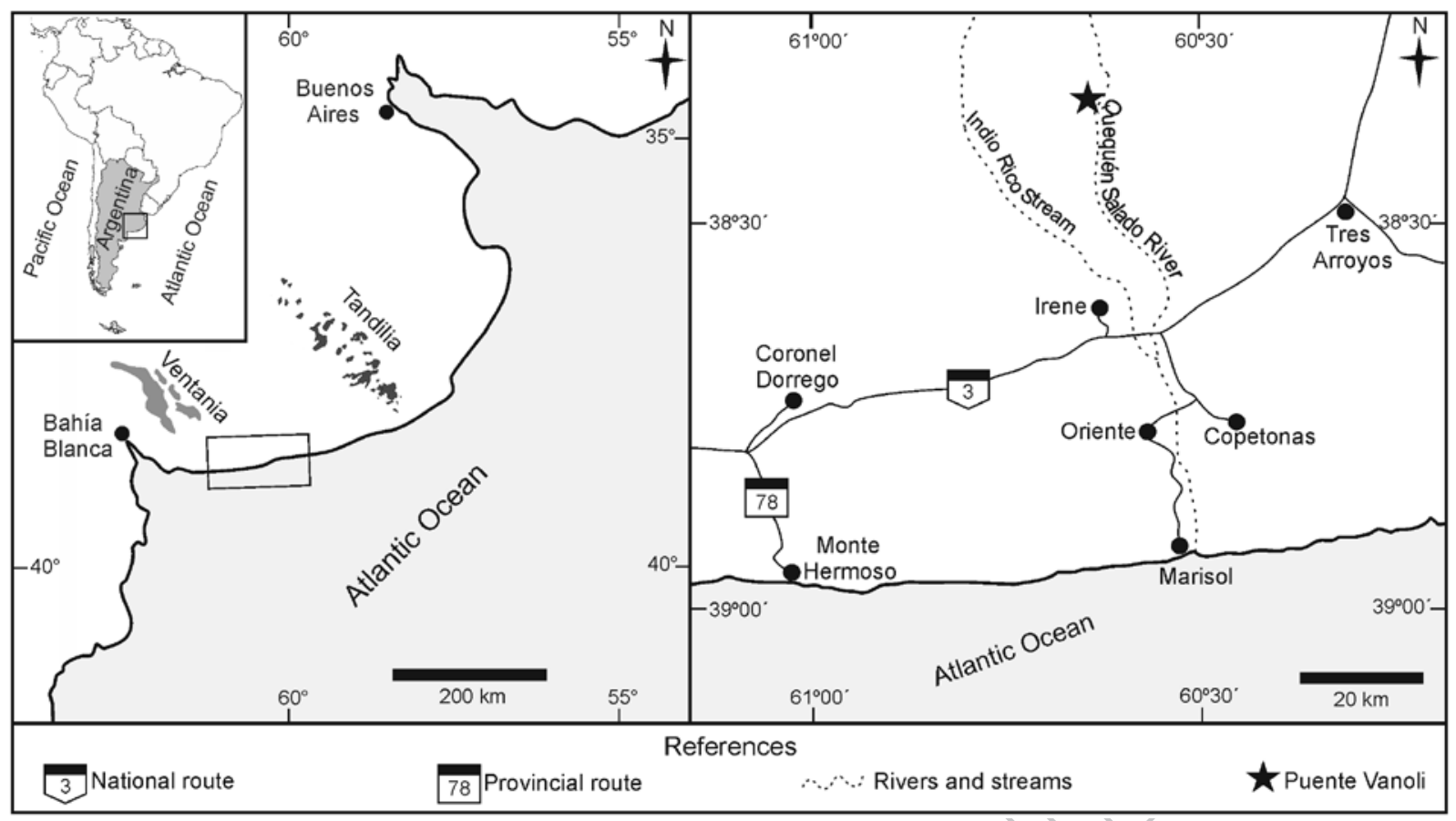

Figure 1. Location map showing Puente Vanoli, Buenos Aires Province, Argentina.

\section{Geographic and stratigraphic setting}

The Pampean Region, extended across central Argentina, is a vast and heterogeneous environment of low relief, that grade from temperate humid conditions north-eastwards to subhumid-semiarid south-westwards. The Neogene-Quaternary cover is composed of fine-grained continental sediments (loess and loess-like deposits) derived from Andean volcanoclastic sources (Zárate 2005; Folguera and Zárate 2009, 2011).

Puente Vanoli locality (S $38^{\circ} 21^{\prime} 23^{\prime \prime}$, W $60^{\circ} 44^{\prime} 20^{\prime \prime}$ ), a river bank exposure along the right margin of the Quequén Salado fluvial system, is situated in the southern area of the Pampean Region, a flat to moderately undulating landscape between the Tandilia and Ventania ranges, known as Bonaerian interrange plain (llanura interserrana bonaerense) (Figure 1). The studied succession is composed of alluvial deposits showing different degree of fluvial reworking (Figure 2(a)). The studied microvertebrates include mammal and reptile specimens. According to the biostratigraphic scheme proposed by Cione and Tonni (2005) and Cione et al. (2015) for the late Cenozoic of the Pampean Region, the presence of Lagostomus maximus assigns the early Holocene-sixteenth century age to the assemblage.

Remains were recovered from the infilling of a small cavity interpreted as a burrow, preserved in a pale greenish yellow (10Y $8 / 2$ ), finely laminated, fine sandy deposit, with carbonatic rhizoconcretions, corresponding to a slightly pedogenised floodplain (facies Fm, Table 1). It is cylindrical in shape, with a straight path, $60-\mathrm{cm}$ long, roughly circular in cross section (major diameter $=26 \mathrm{~cm}$; minor diameter $=24 \mathrm{~cm}$ ), and with an inclination of $65^{\circ}$ (Figure 2(b) and (c)). The infilling is composed of a massive light brown (5YR 6/4) gravelly sand (facies Sm, Table 1). This facies was interpreted as the result of strong, erosive surface run-offs that were channelised by the pre-existing burrow. The remains reported in this paper were concentrated in the lower $25 \mathrm{~cm}$ of the burrow infilling.

Other structures similar in morphology and dimensions to the one studied in this paper were recognised in the same stratigraphic level, and were also interpreted as burrows (Figure (2)). Some of them contained specimens of L. maximus, but no specimens of other taxa were recorded.

\section{Materials and methods}

The mammal and reptile remains recovered from Puente Vanoli are housed at the collection of the Museo de Ciencias Naturales 'Vicente Di Martino' (Monte Hermoso, Buenos Aires Province), under the acronym MMH-QEQ.

A detail sedimentological log was made, considering grain size, lithology, primary sedimentary structures, nature of discontinuities, bioturbation, fossil content, scale and geometry of the lithosomes following Reading and Levell (1996). Sedimentary facies were described according to Miall's scheme $(1978,2006)$. The colour of the sediments was determined using the Rock Colour Chart (Goddard et al. 1948).

Taxonomic identifications were made by comparison with specimens of the mastozoological and paleontological collections of the Museo de La Plata (La Plata, Buenos Aires Province). Microvertebrates include taxa with body masses $<5 \mathrm{~kg}$ (Behrensmeyer 1991).

Micromammal specimens were assigned to two age classes, based on the dental ontogeny and the degree of ossification. Juvenile individuals include specimens with emerging teeth and/or immature bone, with exposed areas of trabecular bone, whereas adult individuals include specimens with permanent teeth and/or mature bone (Behrensmeyer 1991; Montalvo 2004).

Taxonomic and anatomical representation was determined by the following indexes (Badgley 1986): NR (number of recovered 


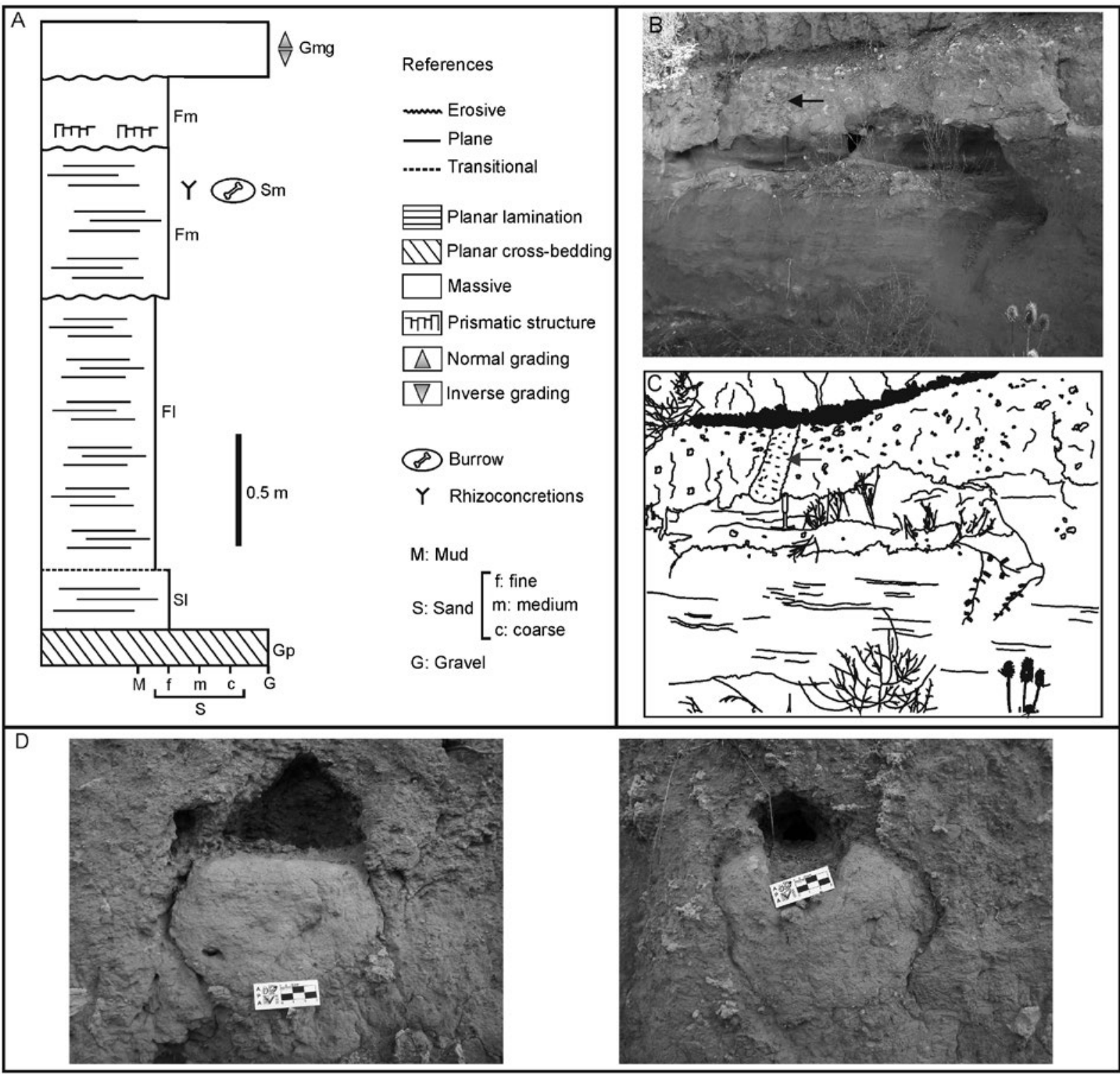

Figure 2. Puente Vanoli. (A) Stratigraphic profile. (B) View of the outcrops. (C) Scheme of the outcrops. Arrows indicate the location of the studied burrow. (D) Other burrows assigned to plains vizcacha from Puente Vanoli.

Table 1. Puente Vanoli lithofacies scheme.

\begin{tabular}{lll}
\hline Facies & Features & Interpretation \\
\hline Gmg & Clast-supported gravel with inverse-normal grading. & Pseudoplastic debris flow \\
& Transitional to crudely bedded pebbly medium sand & \\
Sm & Gravelly fine sand with pebble-sized silt intraclasts. & Deposition from strong, erosive traction currents; \\
& Massive or with faint lamination. Heleobia parchappii & plane-bed flow \\
Fm & Silty fine sand. Massive or with faint lamination & Deposition from aeolian suspension; loess \\
Fl & Interlamination of silt and very fine sand & Suspension fallout and weak traction currents \\
SI & Fine sand, sometimes pebbly. Fine bedding & Plane-bed flow (lower flow regime) \\
Gp & Matrix-supported conglomerate. Planar cross-bed- & Transverse (2D) dunes \\
& ding with wavy erosional base & \\
\hline
\end{tabular}

remains, including both undetermined fragments and specimens identified anatomically and taxonomically), NISP (number of identified specimens per taxon), MNE (minimum number of skeletal elements) and MNI (minimum number of individuals). The MNI was calculated considering the most common element present for each taxon.
Relative abundance (\%Ri) of different skeletal elements was calculated considering the representativeness of each element in the context of the MNI, as follows: $\% \mathrm{Ri}=\mathrm{MNEi} /($ EixMNI $) \times 100$; where MNEi is the minimum number of particular skeletal elements for the sample, and Ei is the expected number of this skeletal element in a given individual (Andrews 1990; Fernández-Jalvo 
Table 2. Micromammal taxa represented in the assemblage. Body mass values correspond to adult individuals.

\begin{tabular}{|c|c|c|c|}
\hline Taxon & Common name & $\mathrm{MNI}$ & Body mass \\
\hline Lestodelphys halli & Patagonian opossum & 2 & 70-100 g (Zapata et al. 2013) \\
\hline Microcavia australis & Southern mountains cavy & 2 & 200-326 g (Tognelli et al. 2001) \\
\hline Reithrodon auritus & Bunny rat & 2 & 20-116 g (Pardiñas and Galliari 2001) \\
\hline Ctenomys sp. & Tuco-tuco & 1 & 120-202 g (Justo et al. 2003) ${ }^{\mathrm{a}}$ \\
\hline Lagostomus maximus & Plains vizcacha & 1 & 3-8.8 kg (Jackson et al. 1996) \\
\hline
\end{tabular}

aalues of Ctenomys talarum, an abundant species of the Pampean Region since the late Pleistocene.

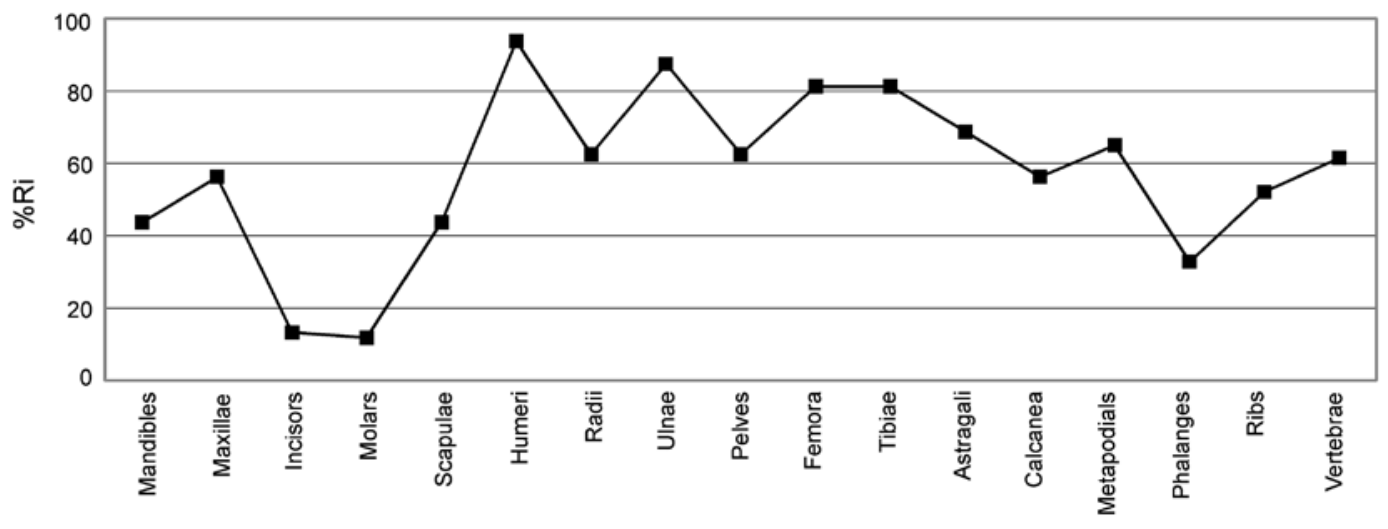

Skeletal elements

Figure 3. Relative abundance (\%Ri) of the skeletal elements for the whole micromammal sample.

and Andrews 1992). This index was calculated for the whole sample as well as individually for each recorded taxon. In the latter case, because of the quantitative differences of certain skeletal elements (e.g. teeth, ribs, vertebrae, metapodials, phalanges) in the different taxa, only those elements represented by two units (paired skeletal elements) in the complete skeleton were evaluated.

The analysis of hydrodynamic sorting followed the groups proposed by Dodson (1973) and Korth (1979) for micromammals, according to the susceptibility of the different skeletal elements to be mobilised by water. The representativeness of each group was determined using the values obtained for NISP and \% Ri.

The following taphonomic features were analysed both on the specimens of the studied assemblage and on the specimens of

30 Lagostomus maximus recoyered from other burrows of Puente Vanoli:

(1) Disarticulation degree, whether the specimens were articulated, disarticulated but associated or disarticulated and isolated (Behrensmeyer 1991).

(2) Breakage degree, whether specimens are complete or incomplete. Four categories were used for skull breakage, including broken skulls without zygomatic region, only maxillae and premaxillae, isolated premaxillae and isolated maxillae (Andrews 1990). Four categories were also used for mandible breakage, including broken ascending ramus, missing ascending ramus, missing ascending ramus and symphysis and ventral border of the dentary broken (Andrews 1990). The breakage degree was also evaluated individually for all the identified taxa, considering only the skeletal elements (mandibles, maxillae, humeri, radii, ulnae, femora, tibiae) that could be assigned to each of them.

The type of fracture (Marshall 1989) was evaluated only in the long bones (humeri, radii, ulnae, femora and tibiae). These elements were also analysed comparing the percentage of proximal, shaft and distal portions (Andrews 1990).

(3) Weathering degree, considers unaltered specimens and specimens with splitting, chipping and/or flaking (Andrews 1990).

(4) Abrasion degree, considers unaltered specimens and specimens with rounding and/or polishing (Alcalá 1994).

(5) Impregnation, encrustation and corrosion degree, considers specimens with fossil-diagenetic modifications (e.g. Andrews 1990; Lyman 1994; Montalvo et al. 2015).

(6) Other modifications, considers specimens with scratch marks (e.g. Andrews and Cook 1985; Behrensmeyer et al. 1986, 1989).

\section{Results}

\subsection{Taxonomic and anatomical representation of the sample}

A total of 949 remains were recovered (NR), of which 211 (22.23\%) correspond to undetermined fragments, both anatomically and taxonomically. The NISP obtained for micromammals was 726 , the MNE 671 and the MNI 8. The NISP obtained for reptiles was 12, the MNE 12 and the MNI 1. 

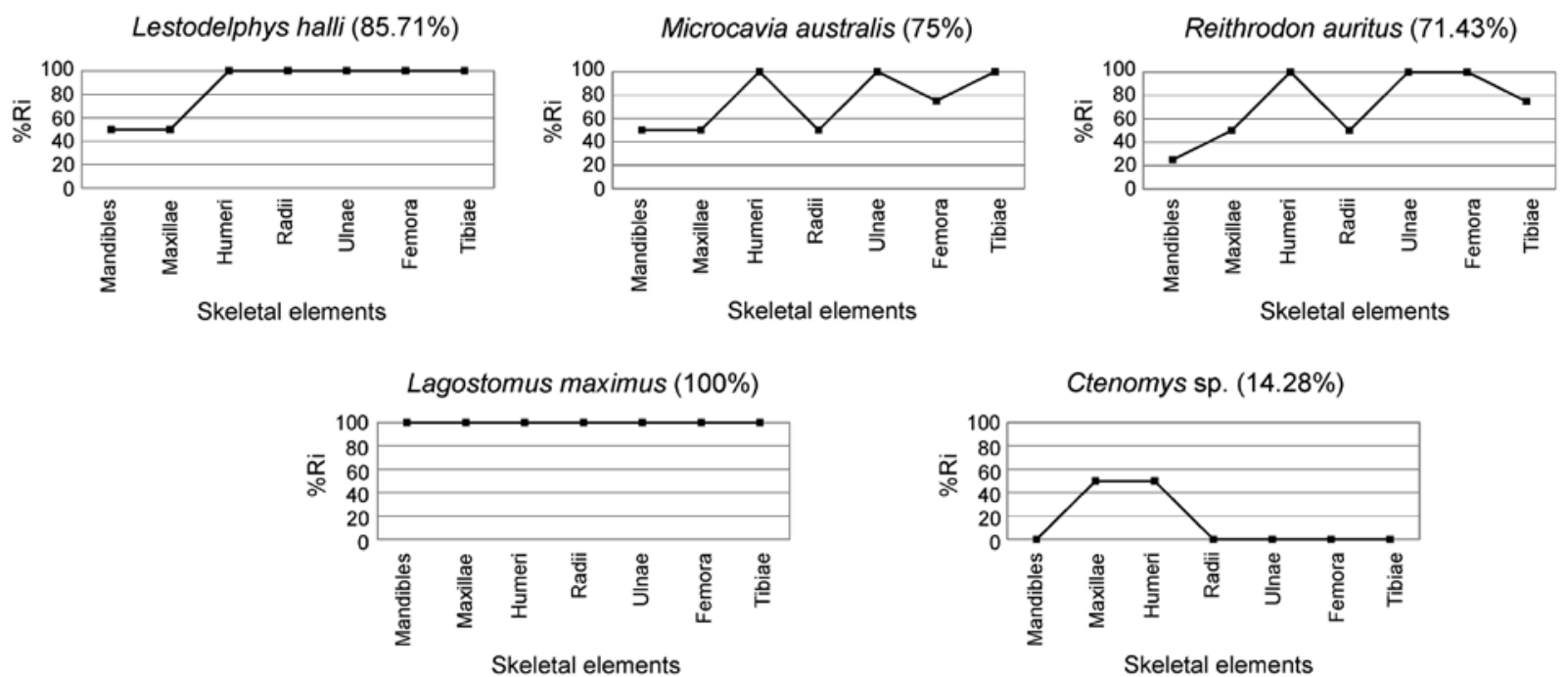

Figure 4. Relative abundance (\%Ri) of the skeletal elements and average values for each micromammal taxa.

Dodson (1973)
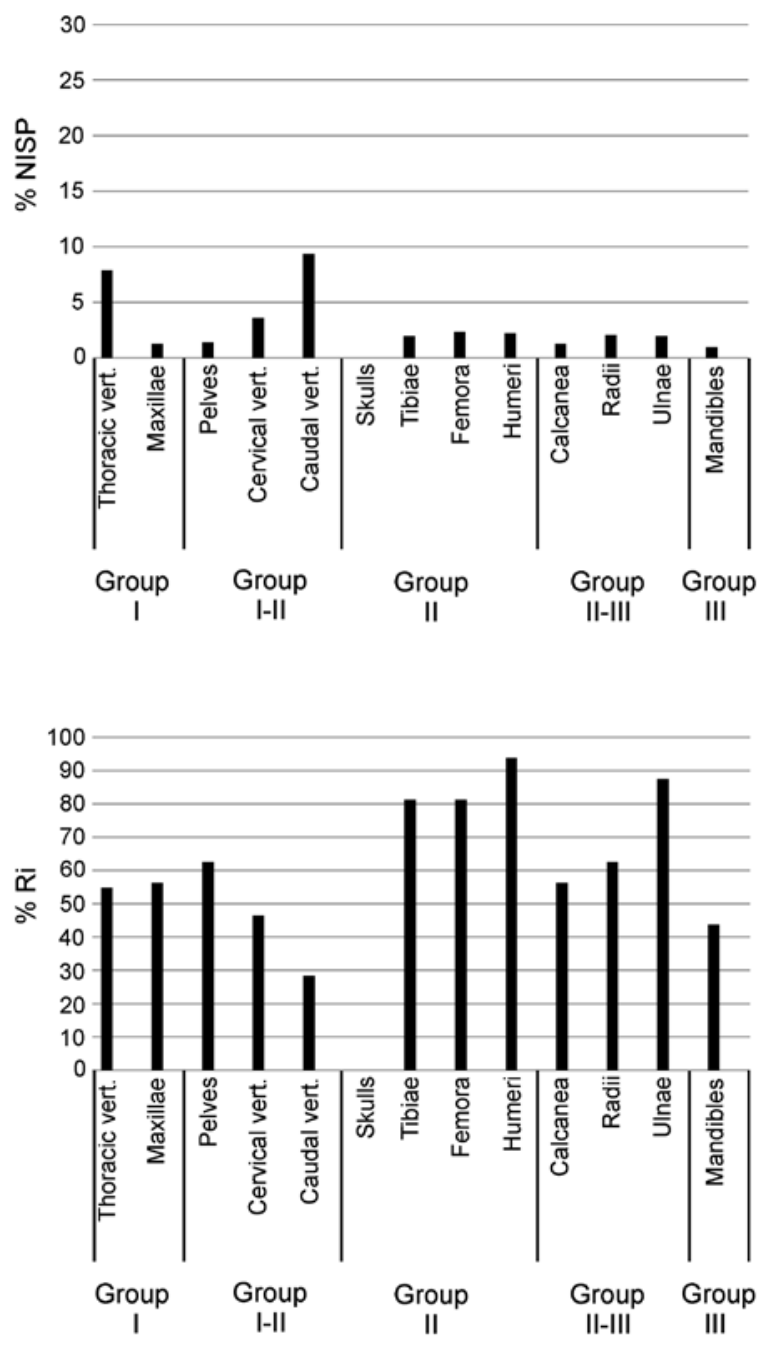

Korth (1979)
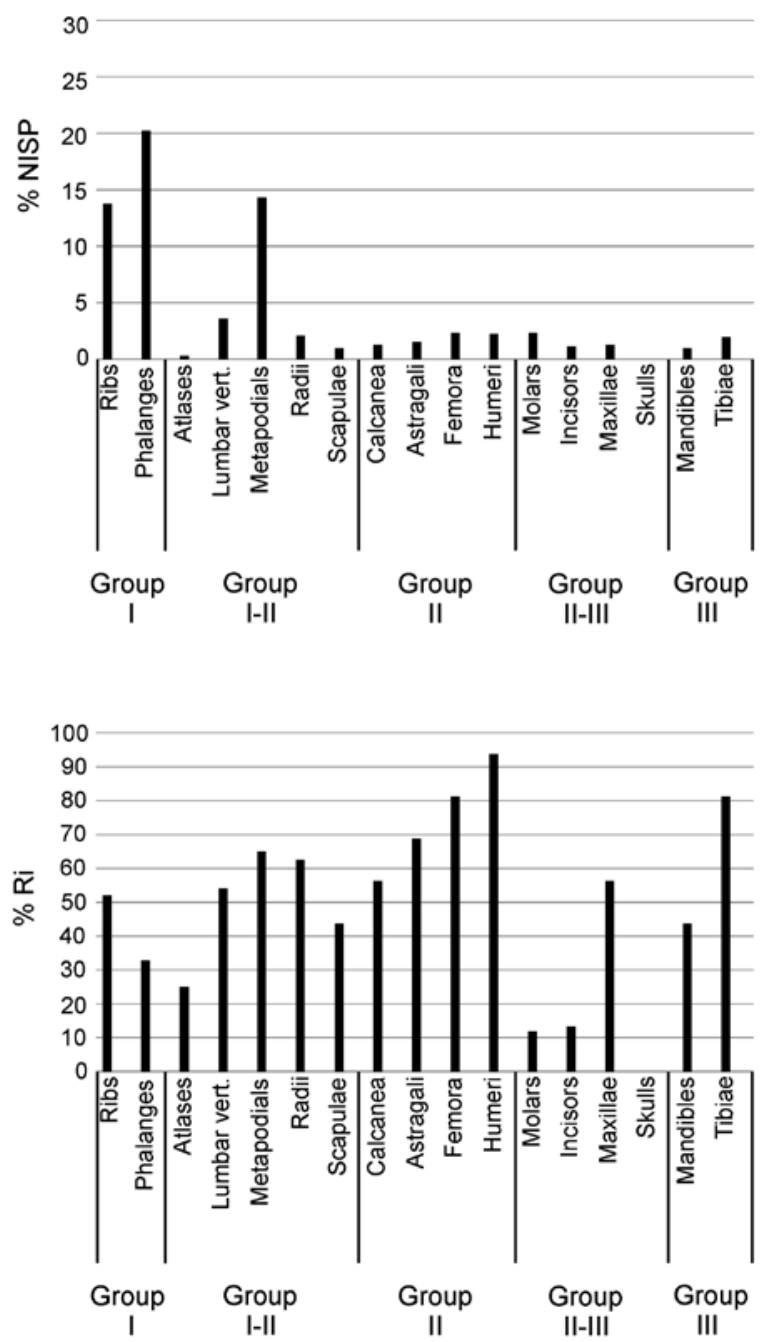

Figure 5. Representation of the micromammal skeletal elements according to Dodson (1973) and Korth (1979) groups. 
(A)

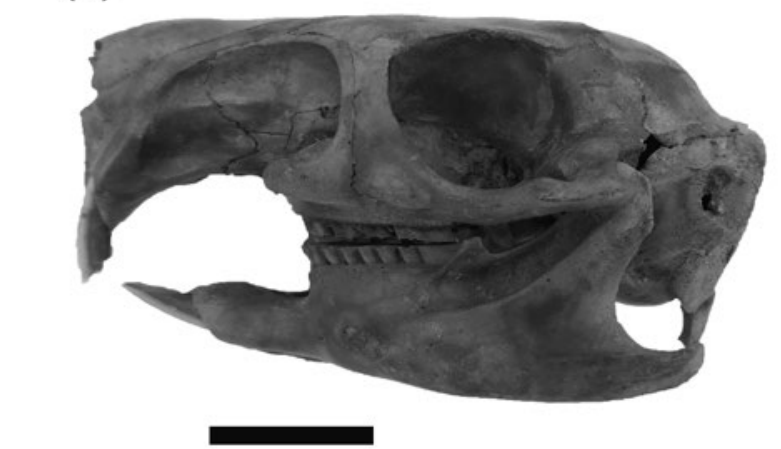

(B)

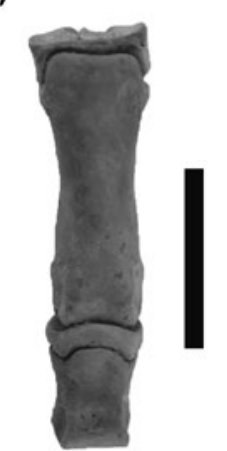

(C)

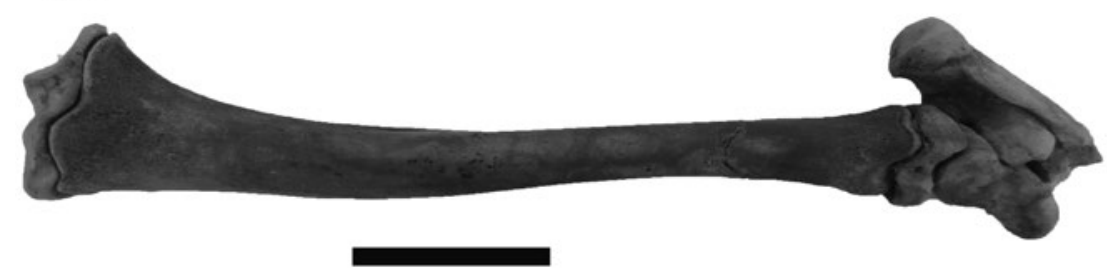

Figure 6. Articulated specimens of Lagostomus maximus. (A) Skull/mandible. (B) Phalanges. (C) Tibia/astragalus/calcaneus. Scale bar $=2 \mathrm{~cm}$.

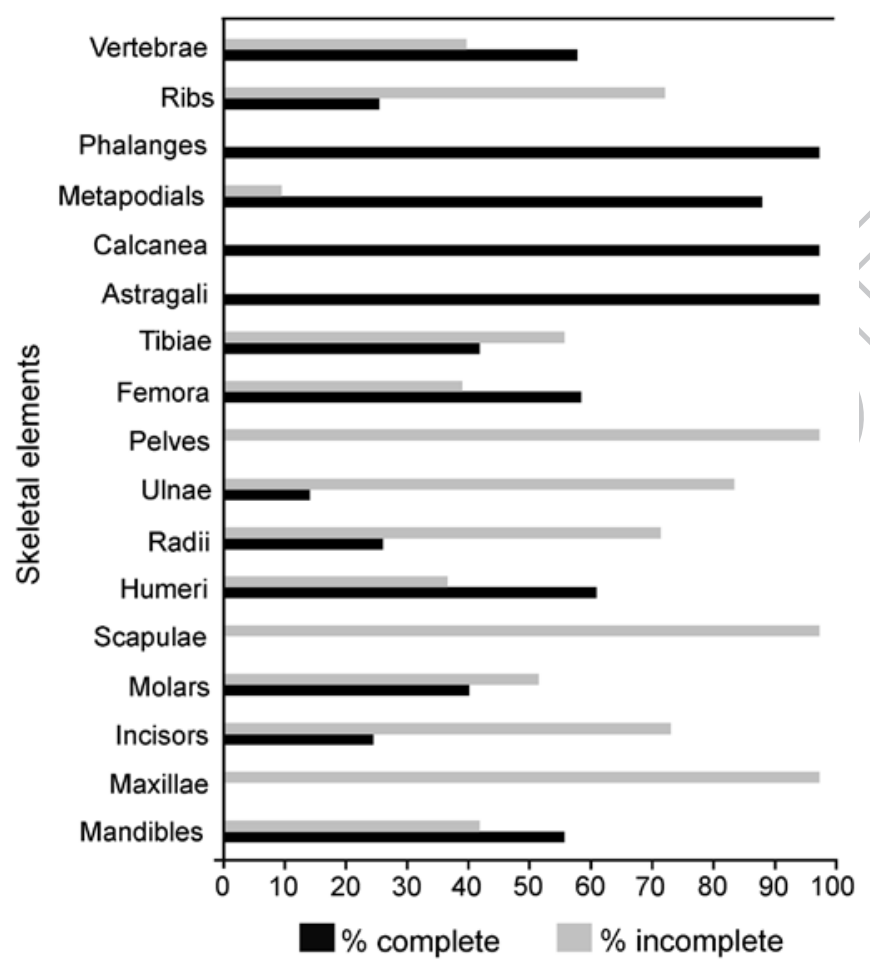

Figure 7. Breakage degree of the micromammal skeletal elements.

From a taxonomic point of view, the didelphid marsupial Lestodelphys halli and different rodents, including the caviid Microcavia australis, the sigmodontine Reithrodon auritus, the chinchillid Lagostomus maximus and the ctenomyine Ctenomys sp., were identified (Table 2). Only the individual belonging to Lagostomus maximus and one of the individuals belonging to Lestodelphys halli were considered juvenile, while the other individuals were considered adults. Reptile specimens correspond to Serpentes indet.
Relative abundance of identified skeletal elements was calculated for the whole micromammal sample, considering an MNI $=8$. Average value of relative abundance was $57.29 \%$. Humeri, ulnae, femora and tibiae were the best represented elements; conversely, incisors and molars were the elements with the lowest representation (Figure 3).

Lagostomus maximus and Lestodelphys halli showed high average values of relative abundance; all skeletal elements were well represented. Microcavia australis and Reithrodon auritus also displayed high average values, but the representativeness of the skeletal elements was variable. Ctenomys sp. evidenced very low average value because it was represented by a few skeletal elements (Figure 4).

The analysis of the micromammal skeletal elements performed on the whole sample, considering their susceptibility to be transported by water currents, allowed the recognition of the different groups proposed by Dodson (1973) and Korth (1979). However, a clear predominance of any group could not be determined (Figure 5).

\subsection{Taphonomic features of micromammals}

\subsubsection{Degree of disarticulation}

Most specimens were considered disarticulated but associated (sensu Behrensmeyer 1991), taking into account the spatial proximity among them and the representativeness values obtained for each taxon. Articulated specimens (sensu Behrensmeyer 1991), with their relative anatomical positions preserved, were scarce and comprised skull/mandible, tibia/astragalus/calcaneus, metapodial/phalange, phalanges and thoracic vertebrae; all of them assigned to Lagostomus maximus (Figure 6(a)-(c)).

\subsubsection{Degree of breakage}

Complete specimens represent $60.06 \%$ of the total (Figure 7 ). Astragali, calcanei, most of the other metapodials and phalanges, were complete. Maxillary fragments, with all teeth 


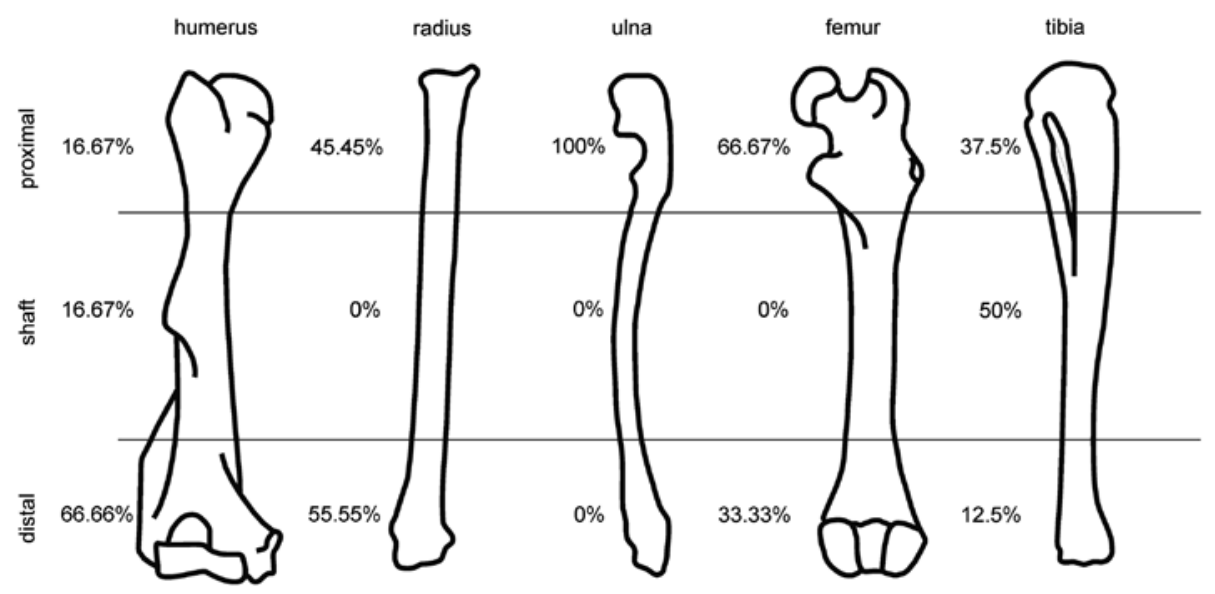

Figure 8. Representation of the different portions of micromammal long bones (modified from Andrews 1990).

or some of them, were the most frequent portion of skulls. Incomplete mandibles were represented by body fragments without the ascending ramus, but retained all teeth or most of them. Teeth retained in the alveoli were complete, whereas isolated teeth showed different degrees of breakage. Scapulae and pelves were incomplete, mainly represented by the articular portions. Ribs were mainly broken in the distal portion, whereas vertebrae generally lacked the apophysis. Long bones showed clear differences in the degree of breakage and the type of preserved portions (Figure 8).

The degree of breakage varied among the recorded taxa. In Lagostomus maximus (28\%) and Lestodelphys halli (37\%) was low, in Microcavia australis (67\%) and Reithrodon auritus (75\%) was high, and in Ctenomys sp. (100\%) was extreme.

Among the incomplete long bones, different types of fractures (sensu Marshall 1989) were identified. Smooth perpendicular fractures were the most abundant (69.77\%), and were identified in specimens assigned to all the recorded taxa. In less proportion, spiral (20.93\%) and longitudinal (9.3\%) fractures were also present, particularly in specimens assigned to Microcavia australis, Reithrodon auritus and Ctenomys sp.

\subsubsection{Degree of weathering}

Evidences of weathering are present in $5.92 \%$ of the specimens. The affected elements included molars, incisors and diverse elements of the limbs, assigned to Microcavia australis, Reithrodon auritus and Ctenomys sp., and also unidentified vertebrae and ribs, which because of their small size cannot be assigned to Lagostomus maximus. They showed slight splitting parallel to fibre structure (category 1; sensu Andrews 1990) (Figure 9(a)). Particularly on teeth, the splitting was limited to the dentine (Figure 9(b)).

\subsubsection{Degree of abrasion}

Evidences of abrasion are present in $3.86 \%$ of the specimens. The affected elements included unidentified scapulae, vertebrae, ribs, metapodials, phalanges and diaphyses; although they cannot be assigned to any particular taxon, the small size rules out their assignment to Lagostomus maximus. Most specimens (2.75\%) only displayed rounding on the edges and ridges (category 2; sensu Alcalá 1994) (Figure 9(c), but others (1.1\%) also evidenced mild polishing on the outer surface (category 3; sensu Alcalá 1994) (Figure 9(e)). Small circular holes were also recognised in some of these specimens, particularly in the areas of bone with thin compact layer (Figure 9(d)).

\subsubsection{Degree of impregnation, encrustation and corrosion}

Impregnation with manganese oxides was identified in $83.2 \%$ of the specimens. Both bones and teeth showed isolated black spots with dendritic habit, located in diverse sectors of the outer surface (Figure $9(\mathrm{f})$ ).

Encrustation was observed in $39.67 \%$ of the specimens. Both bones and teeth displayed small and thin calcareous coatings, light brown colour, covering part of their outer surface. These coatings were superimposed to the black spots (Figure 9(g) and (h)).

Corrosion was recognised in $25.9 \%$ of the specimens. Both bones and teeth, including dentine and enamel, were equally affected. Most of them essentially showed randomly dispersed areas of the outer surface with slight pitting (Figure 9(i) and (j)), nevertheless more extreme cases included surfaces heavily perforated (leaving only small unaffected portions) and original structures (e.g. pores) enlarged (Figure 9(k)). These modifications were superimposed to the black spots and calcareous coatings.

Evidences of impregnation, encrustation and corrosion were present in specimens of all the recorded taxa. No patterns reflecting differential alteration were recognised among different skeletal elements.

\subsubsection{Other modifications}

Scratch marks were recognised only in $1.65 \%$ of the specimens. The affected elements included humeri, femora and tibiae, assigned to Microcavia australis and Reithrodon auritus, and also unidentified metapodials, which because of their small size cannot be assigned to Lagostomus maximus. These marks are isolated, with transversal or oblique orientation respect to the shaft. They showed a narrow and shallow groove, with both V-shaped (Figure 10(a)) and U-shaped (Figure 10(b)) cross section. The values of length and width varied between $590-700 \mu \mathrm{m}$ and $85-115 \mu \mathrm{m}$, respectively. The marks were later affected by other processes such as weathering, encrustation and corrosion (Figure 10(a) and (b)). 
(A)
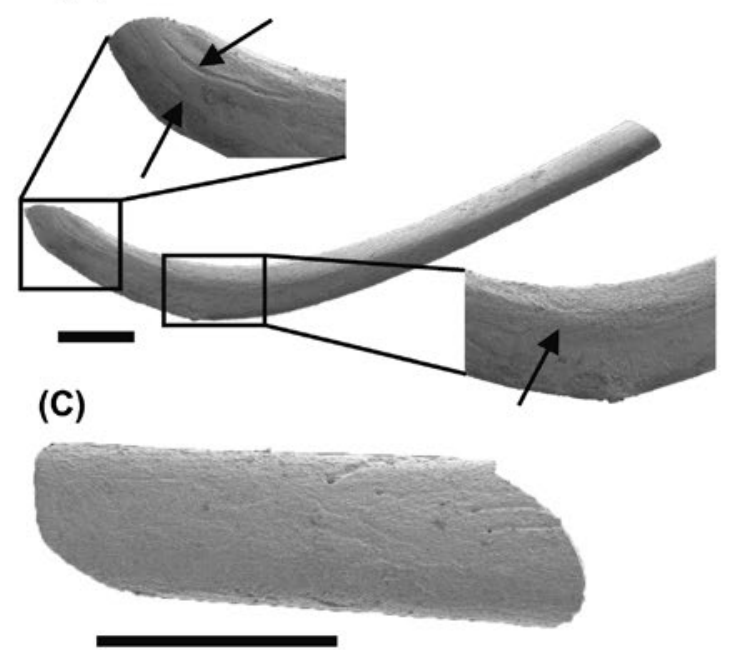

(E)

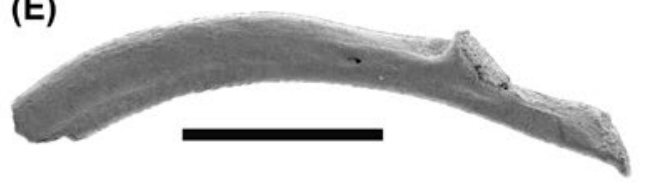

(B)

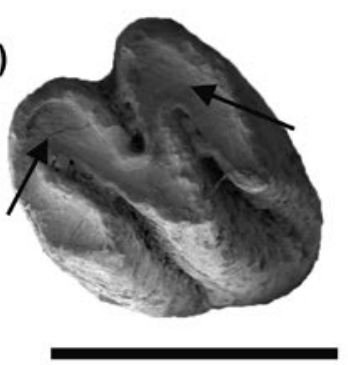

(D)

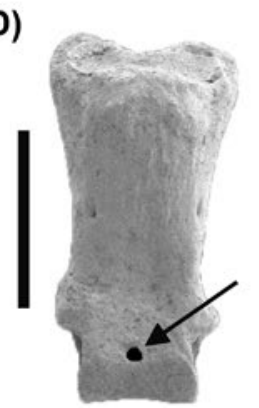

(F)

(H)
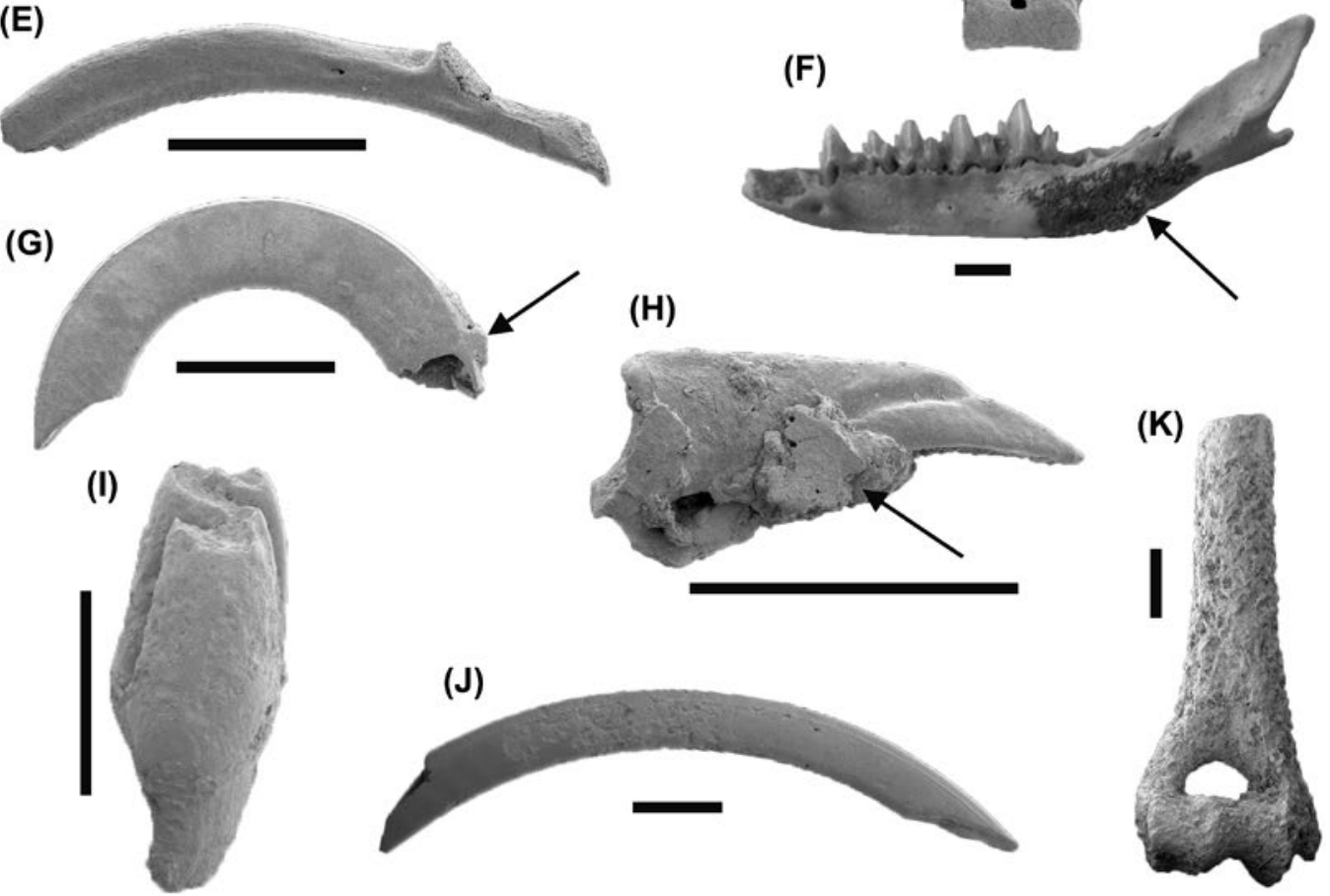

Figure 9. Taphonomic features of micromammal specimens. (A) Rib showing slight splitting parallel to fibre structure (arrows). (B) Molar showing slight splitting of the dentine (arrows). (C) Unidentified diaphysis showing rounding of the edges. (D) Phalange showing polishing of the outer surface and a circular hole (arrow). (E) Rib showing polishing of the outer surface. (F) Hemimandible showing a black spot of manganese oxides (arrow). (G) Incisor showing a calcareous coating (arrow). (H) Phalange showing a calcareous coating (arrow). (I) Molar showing pitting of the dentine and enamel. (J) Incisor showing pitting of the dentine and enamel. (K) Humerus showing pitting of the whole surface. Scale bar $=2 \mathrm{~mm}$.

\subsection{Taphonomic features of reptiles}

The specimens assigned to Serpentes indet. were disarticulated but associated, mostly complete (fractures were recorded only in one maxilla and one hemimandible) and without evidence of weathering, abrasion or scratch marks. Some of them showed evidences of impregnation with manganese oxides, encrustation and corrosion.

\subsection{Taphonomic features of Lagostomus maximus from other burrows of Puente Vanoli}

In these burrows the NISP ranged between 2 and 13 and, in all cases, the MNI was 1. The specimens of Lagostomus maximus mainly included postcranial elements and, in less proportion, also cranial elements. Although some specimens were articulated (e.g. skull/mandibles, thoracic vertebrae), most of them were disarticulated but associated, mostly complete, except for skulls (loss of zygomatic arches) and vertebrae (loss of processes and apophyses), with no weathering, abrasion or trampling signs.

\section{Discussion}

\subsection{Taphonomic analysis}

The studied sample of microvertebrates showed notable concentration of remains in a restricted area both spatially and 25 
(A)

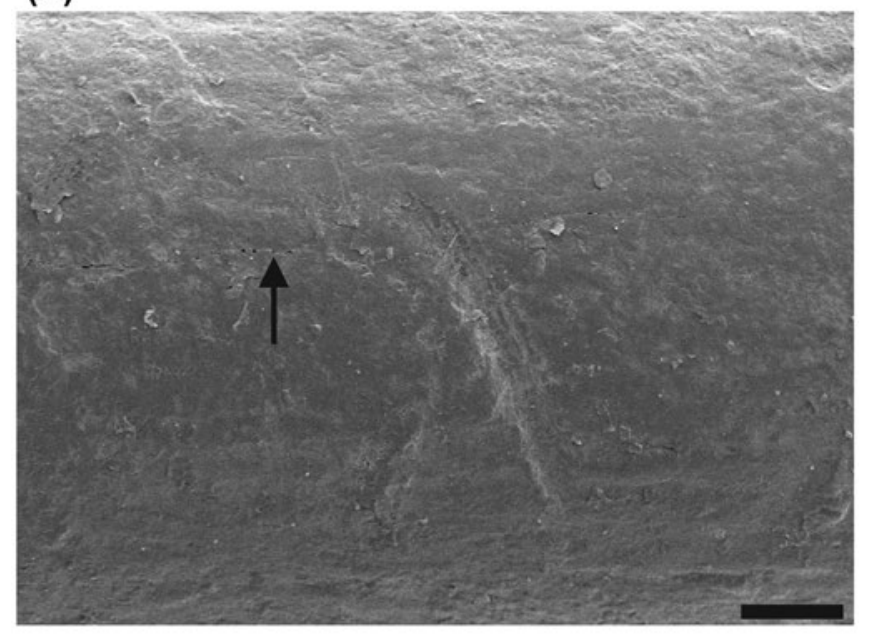

(B)

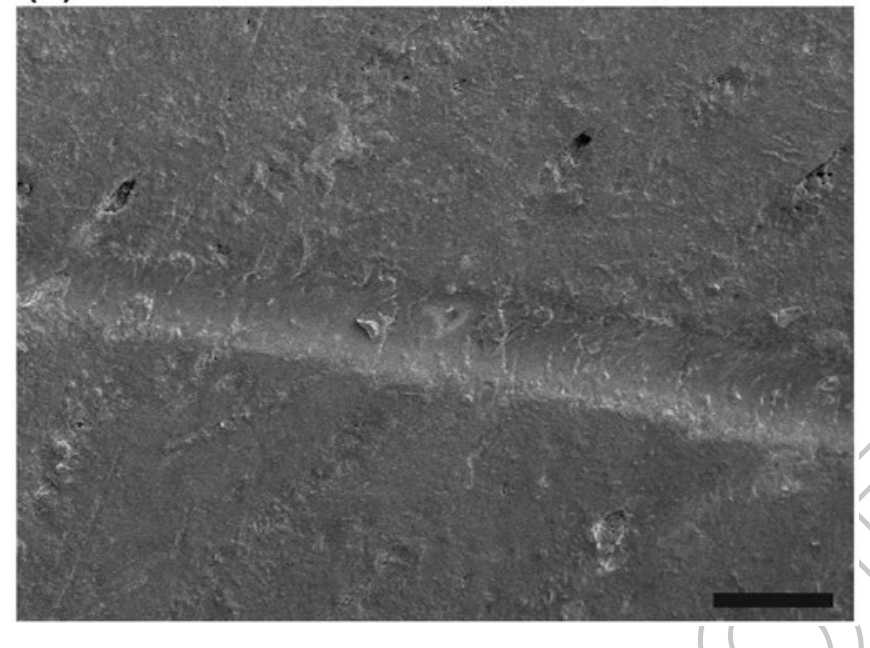

Figure 10. Scratch marks. (A) Mark on a metapodial. Black arrow shows splitting superimposed to the groove. Scale bar $=200 \mu \mathrm{m}$. (B) Mark on a humerus. Scale bar $=100 \mu \mathrm{m}$. In both specimens the marks are modified by corrosion.

stratigraphically, taxonomic diversity (5)marsupial and rodent taxa, and 1 reptile taxon), and abundance of individuals $(\mathrm{MNI}=8)$ with body mass $<5 \mathrm{~kg}$ (in most cases $<350 \mathrm{~g}$ ). These features allowed considering the assemblage as a microfossil bonebed (sensu Eberth et al.2007; Rogers and Eberth 2007).

The whole sample showed a high average value of relative abundance. High average values were determined in Lagostomus maximus and Lestodelphys halli, whereas in Microcavia australis and Reithrodon auritus the values were slightly lower. These results indicate that the carcasses were preserved quite complete. Very low average value obtained in Ctenomys sp. reflects a loss of many skeletal elements.

Dodson (1973), Korth (1979), and Fernández-Jalvo and Andrews (2003) stated that bones of microvertebrates are easily transported and dispersed by water flows of very low speed $(<35 \mathrm{~cm} / \mathrm{s})$, so it is expected that the evidences of sorting are not always clear in assemblages preserved in fluvial environments (see Behrensmeyer 1991). Although the joint analysis of elements assigned to different taxa, with differences in their preservation (e.g. degrees of articulation, weathering and breakage) may partially bias the results (Behrensmeyer 1975; Boaz and Behrensmeyer 1976; Fernández-Jalvo and Andrews 2003), the representation obtained of the different groups of Dodson (1973) and Korth (1979) shows that there was no prevalence of elements of none of the groups, and hence, suggests the absence of hydrodynamic selection. This interpretation is consistent with the good skeletal representation recorded in the sample.

Even discarding the influence of predators and/or scavengers, disarticulation occurs early after the death of organisms, both in aquatic and terrestrial environments (Dodson 1973; Hill 1979; Korth 1979; Hill and Behrensmeyer 1984; Behrensmeyer 1991; Brand et al. 2003). Both disarticulated but associated and articulated specimens, these latter assigned to Lagostmus maximus, reflect rapid burial. In turn, articulated specimens also suggest the presence of soft tissues during burial.

The record of incomplete specimens evidences the action of destructive processes (Behrensmeyer 1991; Lyman 1994). The specimens assigned to Lagostomus maximus, Lestodelphys halli and Serpentes indet., had the highest values of completeness, whereas the specimens assigned to Microcavia australis, Reithrodon auritus and Ctenomys sp. had the lowest values of completeness. These differences are related with the time of exposition to the destructive processes in each case.

Among the complete specimens, autopodial elements were predominant, which are characterised by having compact shape and high values of structural density. Scapulae, pelves, vertebrae and ribs, elements with less resistant and structural density, were intensely affected by breakage. All skulls were incomplete being preserved mostly the maxillae. Most mandibles had a high breakage degree, affecting mainly the area of the ascending ramus. Among teeth, those retained in the alveoli were better preserved. Most robust and resistant long bones such as humeri, femora and tibiae had a lower degree of breakage than the other slender and more fragile such as radii and ulnae.

Most abundant fractures were smooth perpendicular, identified in specimens of every recorded taxon. These fractures are produced after burial, once the bones have lost their organic components and are already mineralised (Shipman 1981; Gifford-Gonzalez 1989).

The spiral fractures, identified in specimens assigned to Microcavia australis, Reithrodon auritus and Ctenomys sp., are produced in fresh bones, commonly due to trampling and activity of predators or scavengers (Behrensmeyer et al. 1989; Fiorillo 1989; Gifford-Gonzalez 1989; Andrews 1990); whereas longitudinal fractures, identified in specimens assigned to Microcavia australis and Reithrodon auritus, are produced after bones have begun to dry out, mainly due to processes of weathering and trampling (Behrensmeyer 1978; Behrensmeyer et al. 1989). The presence of both types of fractures suggests an interval, prior to burial, in which bones were exposed on the surface.

Evidence of weathering reveals that specimens were affected by atmospheric agents, such as sun, wind, rain and temperature changes, among others (Andrews 1990). The identification of slight signs of weathering in specimens assigned to Microcavia australis, Reithrodon auritus and Ctenomys sp., suggests a short time of exposition at the surface (see Korth 1979; Andrews 1990; Behrensmeyer 1991). The absence of weathering signs on specimens of Lagostomus maximus, Lestodelphys halli and Serpentes indet. suggests that the time 
Table 3. Taphonomic features evaluated for the different micromammal taxa represented in the assemblage. Ab, absent; Ar, articulated; Di/As, disarticulated but associated; Lo, longitudinal; $\mathrm{Pr}$, present; Sp, spiral, Tr, transversal.

\begin{tabular}{|c|c|c|c|c|c|}
\hline \multirow[b]{2}{*}{ Taphonomic features } & \multicolumn{5}{|c|}{ Micromammal taxa } \\
\hline & L. halli & M. australis & R. auritus & Ctenomys sp. & L. maximus \\
\hline Relative abundance & $85.71 \%$ & $75 \%$ & $71.43 \%$ & $14.28 \%$ & $100 \%$ \\
\hline Broken elements & $37 \%$ & $67 \%$ & $75 \%$ & $100 \%$ & $28 \%$ \\
\hline Evidence of articulation & $\mathrm{Di} / \mathrm{As}$ & $\mathrm{Di} / \mathrm{As}$ & $\mathrm{Di} / \mathrm{As}$ & $\mathrm{Di} / \mathrm{As}$ & $\mathrm{Ar}$ \\
\hline Evidence of weathering & $\mathrm{Ab}$ & $\operatorname{Pr}$ & $\operatorname{Pr}$ & $\operatorname{Pr}$ & $A b$ \\
\hline Evidence of abrasion & $A b$ & $A b$ & $A b$ & $A b$ & $A b$ \\
\hline
\end{tabular}

of exposition at the surface was very short or null. Differences in weathering degrees allow inferring an assemblage formed by attritional accumulation.

Scratch marks, identified in specimens assigned to Microcavia australis and Reithrodon auritus, show similarities with the trampling marks described by other authors (e.g. Andrews and Cook 1985; Behrensmeyer et al. 1986, 1989). These marks have been

10 affected both by biostratinomic (e.g. weathering) and fossil-diagenetic (e.g. corrosion, encrustation) processes, indicating that the formation may have occurred in a pre-burial stage. However, taking into account the low percentage of affected remains and the modifications produced by posterior processes, it is not possible to interpret with certainty their origin.

The abrasion signs in the specimens are evidence of friction produced by sedimentary particles in movement, although not necessarily of transport distance (Korth 1979; Shipman and Rose 1988; Behrensmeyer 1991). The sparse amount of specimens

20 affected suggests that the time of interaction between remains and sediment was not long or that the intensity was low. The modifications (rounded edges and ridges, polished outer surfaces and circular holes) usually appear immediately in skeletal elements of small mammals exposed to the abrasion action of different types of sediment (see Korth 1979; Fernández-Jalvo and Andrews 2003).

The dark colour identified in specimens of all taxa is related to manganese enrichment provided by water circulating through the host deposits, and its later precipitation as oxides. The formation of these oxides indicates alkaline and oxidising conditions

30 of the environment of preservation during dry periods (LópezGonzález et al. 2006; Marín Arroyo et al. 2008; Tomassini et al. 2014).

Encrustation identified in specimens of all taxa is associated with precipitation of carbonatic salts present in water circulating through the host deposits. The formation of cal-

35 careous coatings was posterior to the impregnations with manganese oxides and indicates alkaline conditions of the environment of preservation during dry periods (Lyman 1994; Fernández-López 2000).

Corrosion identified in specimens of all taxa affected equally randomly dispersed areas of the bones and teeth, and was superimposed to the fossil-diagenetic processes of impregnation and encrustation, indicating a post-burial development. These characteristics differentiate it from the corrosion produced by digestive acids of predators or scavengers (which affects more 45 limited portions of bones and teeth and occurs in pre-burial stages) and link its origin to the interaction with the substrate in which specimens were preserved (see Andrews 1990; FernándezJalvo and Andrews 1992; Fernández-Jalvo et al. 2010). Evidence of intense corrosion recorded both in more organic tissues (bone, dentine) and in mineral-rich tissues (enamel) indicate that specimens were probably affected by the action of humic acids, during wet periods (see Andrews 1990, 1995; Fernández-Jalvo 1995, 2002; Fernández-Jalvo et al. 2002, 2014).

The processes of impregnation, encrustation and corrosion affected the remains in different post-burial stages. The superimposition of these processes suggests that the conditions inside the burrow varied through time.

\subsection{Mammal burrows as taphonomic mode}

Korth (1979) proposed two principal modes of origin for microvertebrate assemblages, including hydrodynamic accumulations and scatological accumulations. Taphonomic features of the studied assemblage suggest that the accumulation of remains inside the burrow was related to the development of flooding processes in the plain. In turn, the absence of marks produced by teeth, beaks or claws and corrosion by digestive acids rule out the participation of predators or scavengers.

Burrows are used by vertebrates as sites of dwelling, shelter from weather, refuge from predators, feeding, mating, aestivation and hibernation (Eisenberg and Kinlaw 1999; Kinlaw 1999; Hasiotis 2002), making them favourable contexts for the preservation of skeletal elements (Behrensmeyer and Hook 1992). The evidences obtained permit to infer that the studied burrow acted as a natural trap, which allowed the accumulation of numerous remains belonging to different microvertebrate taxa, regardless of their mode of death.

The morphometric characteristics of the burrows from Puente Vanoli are consistent with the descriptions of burrows produced by the plains vizcacha that currently inhabit the Pampean Region of Argentina (Hudson 1872; Llanos and Crespo 1952; Branch 1993; Branch et al. 1994). The other micromammal taxa present in the assemblage are also capable of making their own burrows, but the size of these structures is much smaller (Antinuchi and Busch 1992; Pardiñas and Galliari 2001; Tognelli et al. 2001; Martin and Udrizar Sauthier 2011; Melchor et al. 2012). Thus, Lagostomus maximus is proposed as the putative producer of these burrows.

The sedimentological characteristics reflect that the burrow was infilled in a single and rapid event, during the flooding of the plain. This phenomenon produced the gathering and simultaneous burial of remains corresponding to individuals from 
different sources. According to observations on modern contexts, the intraclasts recorded in the infilling could correspond to the material originally accumulated by the plains vizcacha on the surface during excavation, which could have entered the burrow in the flooding event.

The taphonomic features recognised in the specimens assigned to Lagostomus maximus, Lestodelphys halli and Serpentes indet. (Table 3) suggest that the individuals died inside the burrow and their remains were kept there. These interpretations may be extrapolated to the individuals of Lagostomus maximus recovered in the other burrows of Puente Vanoli. In this sense, observation performed on current representatives of plains vizcacha allowed to recognise that, occasionally, the individuals died inside their own burrow.

The taphonomic features recognised in the specimens assigned to Microcavia australis, Reithrodon auritus and Ctenomys sp. (Table 3 ) suggest that the individuals died outside the burrow, their remains were exposed on the surface and then entered the burrow mobilised by surface run-offs. The remains of Microcavia australis and Reithrodon auritus were probably somewhere on the plain near the burrow and consequently, they were barely transported; the few remains of Ctenomys sp. are insufficient to confirm this interpretation.

Several species of mammals, birds, snakes, lizards and amphibians utilise with different purposes the modern burrows of the plains vizcacha, both active and abandoned (e.g. Hudson 1872; Philippi 1873; Villarreal et al. 1995; Jackson et al. 1996; Sironi et al. 2000; Leynaud et al. 2006). The record of specimens assigned to Lestodelphys halli and Serpentes indet. in the burrow produced by Lagostomus maximus could be related to a circumstantial use on the basis of the following considerations: (1) the taphonomic features suggest that the individuals could have died inside the burrow; and (2) Lestodelphys halli can build their nests in abandoned rodent burrows which they recondition (Martin and Udrizar Sauthier 2011) and snakes may use active or abandoned rodent burrows, primarily as shelter from weather and as refuge from predators (Sironi et al. 2000; Rumbo and Cacciali 2008).

Behrensmeyer and Hook (1992) pointed out that burrows are a taphonomic mode characterised by local spatial resolutions and temporal resolutions between $10^{-1}$ and $10^{1}$ years. Accordingly, the taphonomic evidence obtained in this work support a shortterm and low spatial-mixing accumulation, composed by different microvertebrates belonging to the community that inhabited the area.

\section{Conclusions}

The burrow analysed of Puente Vanoli included an assemblage composed by autochthonous and parautochthonous specimens. These specimens correspond to different mammal (rodents and marsupials) and reptile (snake) taxa. Plains vizcacha (Lagostomus maximus) is suggested as the putative producer of this burrow, whereas the Patagonian opossum (Lestodelphys halli) and the snake could have been occasional occupants.

The burrow was a natural trap that favoured the accumulation and preservation of remains. Different pre-burial taphonomic histories were recognised for the individuals, considering that some of them (Lagostomus maximus, Lestodelphys halli,
Serpentes indet.) died inside the burrow and their remains were kept there, whereas others (Microcavia australis, Reithrodon auritus, Ctenomys sp.) died outside the burrow and, after a time of being exposed on the surface, their remains entered the burrow transported by surface run-offs. On the contrary, the post-burial taphonomic histories were similar for all the individuals.

This paper supplies a wealth of data concerning the hydrodynamic accumulation of small vertebrate remains in a taphonomic mode not frequently analysed but which generally present a high preservation potential throughout the fossil record. The information obtained in Puente Vanoli, together with data from previous records allow considering mammal burrows as a relevant taphonomic mode for the late Cenozoic of the Argentine Pampas. The development of burrows in fluvial environments would have favoured the accumulation and preservation of the remains of: (1) organisms producers of burrows; (2) organisms that circumstantially used the burrows; and (3) organisms that inhabited the areas surrounding the burrows and that, after their death, were mobilised inside the burrows. Based on the comparison with modern fauna, this paper also provides information about paleoecologic issues of taxa that inhabited the south of the Pampean Region during the Holocene.

\section{Acknowledgements}

We thank N. Sánchez, director of the Museo Municipal de Ciencias Naturales 'Vicente Di Martino', for the access to the studied materials. C. Gutiérrez Ayesta helped with the SEM photographs. M. De los Reyes, G. Martin and D. Villarreal provided useful information about the Patagonian opossum Lestodelphys halli and the plains vizcacha Lagostomus maximus. Thanks are extended to P. Andrews, an anonymous reviewer, and the editor G. Dyke, whose comments and suggestions have greatly improved this manuscript.

\section{Disclosure statement}

No potential conflict of interest was reported by the authors.

\section{Funding}

This work was supported by CONICET and grants [PICT 2012-2674], [PICT 2010-0804], [PIP 0496], FCEyN (UNLPam) 209.

\section{References}

Alberdi MT, Menegaz AN, Prado JL, Tonni EP. 1989. La Fauna local Quequén Salado-Indio Rico (Pleistoceno tardío) de la provincia de Buenos Aires, Argentina. Aspectos paleoambientales y bioestratigráficos. Ameghiniana. 25(3):225-236.

Alcalá L. 1994. Macromamíferos neógenos de la fosa de Alfambra-Teruel. Teruel: Instituto de estudios Turolenses y Museo Nacional de Ciencias Naturales. p. 554.

Andrews P. 1990. Owls, caves and fossils predation, preservation, and accumulation of small mammal bones in caves, with the analysis of the Pleistocene cave faunas from Westbury-sub-Mendip, Somerset, UK. London: Natural History Museum Publications. p. 231.

Andrews P. 1995. Experiments in taphonomy. J Archaeol Sci. 22(2):147153.

Andrews P, Cook J. 1985. Natural modifications to bones in a temperate setting. Man. 20(4):675-691.

Antinuchi CD, Busch C. 1992. Burrow structure in the subterranean rodent Ctenomys talarum. Z Säugetierkd. 57(3):163-168. 
Badgley C. 1986. Counting individuals in mammalian fossil assemblages from fluvial environments. Palaios. 1(3):328-338.

Behrensmeyer AK. 1975. The taphonomy and paleoecology of PlioPleistocene vertebrate assemblages of Lake Rudolf, Kenya. Bull Museum Comp Zool. 146:473-578.

5 Behrensmeyer AK. 1978. Taphonomic and ecologic information from bone weathering. Paleobiology. 4(2):150-162.

Behrensmeyer AK. 1991. Terrestrial vertebrate accumulations. In: Stehli FG, Jones DEG, editors. Taphonomy: releasing the data locked in the fossil record. New York (NY): Plenum Press. p. 291-335.

Behrensmeyer AK, Gordon KD, Yanagi GT. 1986. Trampling as a cause of bone surface damage and pseudo-cutmarks. Nature. 319:768-771.

Behrensmeyer AK, Gordon K, Yanagi G. 1989. Nonhuman bone modification in Miocene fossils from Pakistan. In: Bonnichsen R, Sorg M, editors. Bone modification. Orono: Institute for Quaternary Studies, University of Maine. p. 99-120.

Behrensmeyer AK, Hook RW. 1992. Paleoenvironmental contexts and taphonomic modes. In: Behrensmeyer AK, Damuth JD, DiMichele WA, Potts R, Sues H, Wings SL, editors. Terrestrial ecosystems through time: evolutionary paleoecology of terrestrial plants and animals. Chicago (IL): University of Chicago Press. p. 15-136.

Beilinson E, Taglioretti M. 2013. Análisis icnológico y paleoambiental de la Aloformación Punta San Andrés (Plio-Pleistoceno), provincia de

AOP13 Buenos Aires, Argentina. Ameghiniana. 50(2):153-165.

Boaz N, Behrensmeyer AK. 1976. Hominid taphonomy: transport of human skeletal parts in an artificial fluviatile environment. Am J Phys Anthropol. 45(1):53-60.

Branch LC. 1993. Social organization and mating system of the plains vizcacha (Lagostomus maximus). J Zool. 229(3):473-491.

25 Branch LC, Villarreal D, Sosa RA, Pessino M, Machicote M, Lerner P, Borraz P, Urioste M, Hierro JL. 1994. Estructura de las colonias de vizcacha y problemas asociados con la estimación de la densidad poblacional en base a la actividad de las vizcacheras. Mastozool Neotrop. 1(2):135-142.

Brand LR, Hussey M, Taylor J. 2003. Decay and disarticulation of small

AQ15 vertebrates in controlled experiments. J Taphon. 1(2):69-95.
30 Cenizo MM, De los Reyes LM. 2008. Primeros registros de Tyto alba (Scopoli, 1769) (Strigiformes, Aves) en el Pleistoceno Medio-Tardío de la provincia de Buenos Aires (Argentina) y sus implicancias tafonómicas. Rev Mus Argent Cienc Nat. 10(2):199-209.

AQ16

Cenizo MM, Soibelzon E, Magnussen Saffer M. 2015. Mammalian predator-prey relationships and reoccupation of burrows in the Pliocene of the Pampean Region (Argentina): new ichnological and taphonomic evidence. Hist Biol. doi: http://dx.doi.org/10.1080/08912963.2015.1089868.

Cione AL, Gasparini GM, Soibelzon E, Soibelzon LH, Tonni EP. 2015. The great American biotic interchange: a South American perspective. New York (NY): Springer. p. 97.

40 Cione AL, Tonni EP. 2005. Bioestratigrafía basada en mamíferos del Cenozoico superior de la provincia de Buenos Aires, Argentina. In: de Barrio RE, Etcheverry RO, Caballé MF, Llambías E, editors. Geología y Recursos Minerales de la Província de Buenos Aires. La Plata: XVI Congreso Geológico Argentino. p. 183-200.

Dodson P. 1973. The significance of small bones in paleoecological interpretation. Contrib Geol. 12(1):15-19.

Eberth DA, Shannon M, Noland BG. 2007. A bonebeds database: classification, biases, and patterns of occurrence. In: RR Rogers, DA Eberth, AR Fiorillo, editors. Bonebeds. Genesis, analysis, and paleobiological significance. Chicago (IL): The University of Chicago Press. p. 103-220.

50 Eisenberg JF, Kinlaw A. 1999. Introduction to the special issue: ecological significance of open burrow systems. J Arid Environ. 41(2):123-125.

Elissamburu A, Dondas A, De Santis L. 2011. Morfometría de las paleocuevas de la "Fm." Chapadmalal y su asignación a Actenomys (Rodentia), Paedotherium (Notoungulata) y otros mamíferos fósiles

AQ19 hospedantes. Mastozool Neotrop. 18(2):227-238.
55 Fernández-Jalvo Y. 1995. Small mammal taphonomy at La Trinchera de Atapuerca (Burgos, Spain). A remarkable example of taphonomic criteria used for stratigraphic correlations and palaeoenvironment interpretations. Palaeogeogr Palaeoclimatol Palaeoecol. 114:167-195.
Fernández-Jalvo Y, Andrews P. 1992. Small mammal taphonomy of Gran Dolina, Atapuerca (Burgos), Spain. J Archaeol Sci. 19(4):407-428.

Fernández-Jalvo Y, Andrews P. 2003. Experimental effects of water abrasion on bone fragments. J Taphon. 1(3):147-163.

Fernández-Jalvo Y, Andrews P, Pesquero D, Smith C, Marín-Monfort D, Sánchez B, Geigl EM, Alonso A. 2010. Early bone diagenesis in temperate environments. Palaeogeogr Palaeoclimatol Palaeoecol. 288:62-81.

Fernández-Jalvo Y, Andrews P, Sevilla P, Requejo V. 2014. Digestion versus abrasion features in rodent bones. Lethaia. 47(3):323-336.

Fernández-Jalvo Y, Sanchez-Chillon B, Andrews P, Fernandez-Lopez S, Alcala Martinez L. 2002. Morphological taphonomic transformations of fossil bones in continental environments, and repercussions on their chemical composition. Archaeometry. 44(3):353-361.

Fernández-López S. 2000. Temas de Tafonomía. Madrid: Departamento de Paleontología, Universidad Complutense de Madrid. p. 167.

Folguera A, Zárate MA. 2009. La sedimentación neógena continental en el sector extrandino de Argentina central. Rev Asoc Geol Argent. 64(4):692-712.

Folguera A, Zárate MA. 2011. Neogene sedimentation in the foreland zone between $34^{\circ} 30^{\prime}$ and $41^{\circ} \mathrm{S}$ and its relation to the Pampa Central block uplift and the tectonic Colorado basin. In: Salfity JA, Marquillas RA, editors. Cenozoic geology of the central Andes of Argentina. Salta: SCS. p. $121-132$.

Genise JF. 1989. Las cuevas de Actenomys (Rodentia: Octodontidae) de la Formación Chapadmalal (Plioceno superior) de Mar del Plata y Miramar (Provincia de Buenos Aires). Ameghiniana. 26(1):33-42.

Gifford-Gonzalez D. 1989. Ethnographic analogues for interpreting modified bones: some cases from East Africa. In: Bonnichsen R, Sorg M, editors. Bone modification. Orono: Institute for Quaternary Studies, University of Maine. p. 179-246.

Goddard E, Trask P, De Ford R, Rove O, Singewald J, Overbeck R. 1948. Rock color chart. Washington (DC): National Research Council. p. 8.

Hasiotis ST. 2002. Continental trace fossils. Oklahoma, OK: SEPM Short Course. p. 134.

Hill A. 1979. Disarticulation and scattering of mammal skeletons. Paleobiology. 5(3):261-274.

Hill A, Behrensmeyer AK. 1984. Disarticulation patterns of some modern east African mammals. Paleobiology. 10(3):366-376.

Hudson WH. 1872. On the habits of the vizcacha (Lagostomus trichodactylus). Proc Zool Soc London. 1872:822-833.

Jackson JE, Branch LC, Villarreal D. 1996. Lagostomus maximus. Mamm Species. 543:1-6.

Justo ER, De Santis LJM, Kin MS. 2003. Ctenomys talarum. Mamm Species. 730:1-5.

Kinlaw A. 1999. A review of burrowing by semi-fossorial vertebrates in arid environments. J Arid Environ. 41(2):127-145.

Korth W. 1979. Taphonomy of microvertebrate fossil assemblages. Ann Carnegie Mus. 48:235-285.

Leynaud GC, Pelegrin N, Lescano JN. 2006. Anfibios y Reptiles. In: Bucher $\mathrm{EH}$, editor. Bañados del río Dulce y Laguna Mar Chiquita, Córdoba, Argentina. Córdoba: Academia Nacional de Ciencias. p. 219-235. AQ18 AQ21

Llanos AC, Crespo JA. 1952. Ecología de la vizcacha (Lagostomus maximus maximus Blainville) en el nordeste de la Provincia de Entre Ríos. Rev Invest Agríc. 6(3):289-378.

López-González F, Grandal-d’Anglade A, Vidal-Romaní J. 2006. Deciphering bone depositional sequences in caves through the study of manganese coatings. J Archaeol Sci. 33(5):707-717.

Lyman RL. 1994. Vertebrate taphonomy. Cambridge: Cambridge University Press. p. 524.

Marín Arroyo AB, Landete Ruiz MD, Vidal Bernabeu G, Seva Román R, González Morales MR, Straus LG. 2008. Archaeological implications of human-derived manganese coatings: a study of blackened bones in $\mathrm{El}$ Mirón Cave, Cantabrian Spain. J Archaeol Sci. 35(3):801-813.

Marshall L. 1989. Bone modification and "The laws of burial". In: Bonnichsen R, Sorg M, editors. Bone modification. Orono: Institute for Quaternary Studies, University of Maine. p. 7-24.

Martin GM, Udrizar Sauthier DE. 2011. Observations on the captive behavior of the rare Patagonian opossum Lestodelphys halli (Thomas, 
1921) (Marsupialia, Didelphimorphia, Didelphidae). Mammalia. 75(3):281-286.

Melchor RN, Genise JF, Umazano AM, Superina M. 2012. Pink fairy armadillo meniscate burrows and ichnofabrics from Miocene and Holocene interdune deposits of Argentina: Palaeoenvironmental and palaeoecological significance. Palaeogeogr Palaeoclimatol Palaeoecol. 350-352:149-170.

AQ23

Miall AD. 1978. Lithofacies types and vertical profile models in braided river deposits: a summary. In: Miall AD, editor. Fluvial sedimentology. Ontario: Canadian Society of Petroleum Geologists, Memoir 5. p. 597 604.

Miall AD. 2006. The geology of fluvial deposits Sedimentary facies, basin analysis and petroleum geology. New York (NY): Springer-Verlag. p. 582.

Montalvo CI. 2004. Paleobiología de la asociación faunística de Caleufú (La Pampa, Formación Cerro Azul, Mioceno superior-Plioceno inferior) a través de análisis tafonómicos [Ph.D. thesis]. La Plata: Facultad de Ciencias Naturales y Museo, Universidad Nacional de La Plata.

Montalvo CI, Tomassini RL, Sostillo R. 2015. Leftover prey remains: a new taphonomic mode from the Late Miocene Cerro Azul Formation of Central Argentina. Lethaia. doi: http://dx.doi.org/10.1111/let.12140.

\section{AQ25}

Montalvo CI, Tomassini RL, Visconti G, Tiranti S. 2012. Análisis tafonómico de micromamíferos del Pleistoceno Superior del Quequén Salado, provincia de Buenos Aires, Argentina. Rev Brasil Paleontol.

AQ26 15(3):345-358.

Pardiñas UFJ. 2001. Condiciones áridas durante el Holoceno Temprano en el sudoeste de la provincia de Buenos Aires (Argentina): vertebrados y

AQ27 tafonomía. Ameghiniana. 38(3):227-236.
A65 Pardiñas UFJ. 2004. Roedores sigmodontinos (Mammalia: Rodentia: Cricetidae) y otros micromamíferos como indicadores de ambientes hacia el Ensenadense cuspidal en el sudeste de la provincia de Buenos

AQ28 Aires (Argentina). Ameghiniana. 41(3):437-450.

Pardiñas UFJ, Galliari C. 2001. Reithrodon auritus. Mamm Species. 664:1-8.

Pardiñas UFJ, Gelfo JN, San Cristóbal J, Cione AL, Tonni EP. 1996. Una asociación de organismos marinos y continentales en el Pleistoceno Superior en el sur de la provincia de Buenos Aires, Argentina. Resúmenes XIII Congreso Geológico Argentino y III Congreso de

AQ29 Exploración de Hidrocarburos. p. 95-111.

Peña MI. 1997. Tafonomía de restos óseos y condiciones ambientales del Plioceno Tardío, Playa San Carlos (Pdo. de Gral. Pueyrredón) [MSc thesis]. Mar del Plata: Facultad de Ciencias Exactas y Naturales,

AQ30 Universidad Nacional de Mar del Plata.

Philippi RA. 1873. Ueber die Boa der westlichen Provinzen der Argentinischen Republik. Zeitsch Gesammte Naturwise. 41:127-130.
Reading HG, Levell BK. 1996. Controls on the sedimentary rock record. In: Reading HG, editor. Sedimentary environments processes, facies and stratigraphy. Oxford: Blackwell Science. p. 5-36.

Rogers RR, Eberth DA. 2007. A conceptual framework for the genesis and analysis of vertebrate skeletal concentrations. In: RR Rogers, DA Eberth, AR Fiorillo, editors. Bonebeds Genesis, analysis, and paleobiological significance. Chicago (IL): The University of Chicago Press. p. 1-64.

Rumbo MF, Cacciali P. 2008. Nota sobre la fauna herpetológica en cuevas de Ctenomys pearsoni (Rodentia, Ctenomyidae). Kempffiana. 4(2):1317.

Scognamillo DG. 1993. Estructuras de las cuevas de Actenomys (Rodentia: Octodontidae) de la Aloformación Playa San Carlos, Plioceno tardío (Barranca de los Lobos, Pdo. Gral. Pueyrredón): significado paleoecológico y estratigráfico [MSc thesis]. Mar del Plata: Facultad de Ciencias Exactas y Naturales, Universidad Nacional de Mar del Plata.

Shipman P. 1981. Life history of a fossil: an introduction to taphonomy and paleoecology. Harvard: Harvard University Press. p. 222.

Shipman P, Rose J. 1988. Bone tools. An experimental approach. In: Olsen SL, editor. Scanning electron microscopy in archaeology. Oxford: British Archaeological Reports International Series. p. 303-335.

Sironi M, Chiaraviglio M, Cervantes R, Bertona M, Rio M. 2000. Dietary habits of Boa constrictor occidentalis in the Cordoba Province, Argentina. Amphibia Reptilia. 21:226-232.

Tognelli MF, Campos CM, Ojeda RA. 2001. Microcavia australis. Mamm Species. 648:1-4.

Tomassini RL, Montalvo CI. 2013. Taphonomic modes on fluvial deposits of the Monte Hermoso Formation (early Pliocene), Buenos Aires province, Argentina. Palaeogeogr Palaeoclimatol Palaeoecol. 369:282294.

Tomassini RL, Montalvo CI, Manera T, Visconti G. 2014. Mineralogy, geochemistry and paleohistology of Pliocene mammals from the Monte Hermoso Formation (Argentina). Paedotherium bonaerense (Notoungulata, Hegetotheriidae) as case study. Ameghiniana. 51(5):385-395.

Villarreal D, Machicote M, Branch LC, Martinez JJ, Gopar A. 1995. Habitat patch size and local distribution of burrowing owls (Athene Cunicularia) in Argentina. Ornitol Neotrop. 16(4):529-537.

Zapata SC, Procopio D, Travaini A, Rodríguez A. 2013. Summer food habits of the Patagonian opossum, Lestodelphys halli (Thomas, 1921), in southern arid Patagonian shrub-steppes. Gayana. 77(1):64-67.

Zárate MA. 2005. El Cenozoico tardío continental de la provincia de Buenos Aires. In: de Barrio RE, Etcheverry RO, Caballé MF, Llambías E, editors. Geología y Recursos Minerales de la Provincia de Buenos Aires. La Plata: XVI Congreso Geológico Argentino. p. 139-158. 